\title{
Eco-Friendly and Integrated Approaches for Management of Early Blight Disease in Tomato
}

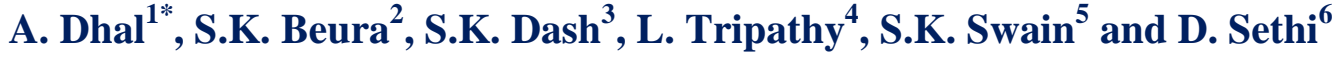 \\ ${ }^{1}$ Plant Pathologist, AICRP on Groundnut, OUAT, Bhubaneswar, India \\ ${ }^{2}$ Plant Pathology, College of Agriculture, OUAT, Bhubaneswar, India \\ ${ }^{3}$ Vegetable Specialist, AICVIP, OUAT, Bhubaneswar, India \\ ${ }^{4}$ Horticulture, College Of Forestry, OUAT, Bhubaneswar, India \\ ${ }^{5}$ Agronomist, AICRP on Groundnut, OUAT, Bhubaneswar, India \\ ${ }^{6}$ Department of Soil Science and Agricultural Chemistry, OUAT, Bhubaneswar, Odisha, India \\ *Corresponding author
}

\section{A B S T R A C T}

Field experiments were conducted for three consecutive seasons of Rabi 2010-11, 2011-12 and 2012-13 in the farmer's field of Jagatsinghpur district of Odisha in order to study the synergistic effect of cultural practice, seed priming and foliar spray with bioagents on management of Alternaria blight of tomato. The trial was laid out in Randomized Block

\section{Keywords}

Alternaria solani, Bioagents, Cultural practice, Seed priming.

Article Info

Accepted:

26 September 2017

Available Online:

10 October 2017
Design comprising ten treatments and three replications with individual plot size of $8.1 \mathrm{~m}^{2}$ $(3.0 \times 2.7 \mathrm{~m})$. The planting was made with a spacing of $60 \mathrm{~cm} \times 40 \mathrm{~cm}$ with recommended dose of fertilizer such as 125:60:100 Kg N$: \mathrm{P}_{2} \mathrm{O}_{5}: \mathrm{K}_{2} \mathrm{O} /$ ha. Removal of infected lower leaves, staking of tomato plants, seed priming with Trichoderma viride followed by foliar spraying with Trichoderma viride and Pseudomonas fluoroscens recorded the minimum PDI of 3.4\%, 5.8\% respectively reducing the early blight incidence by $93.4 \%$ and $88.8 \%$ respectively over control. Removal of infected lower leaves, staking of plants, seed priming and foliar spray of Trichoderma viride gave maximum fruit yield of $328.4 \mathrm{q} / \mathrm{ha}$ followed by $324.9 \mathrm{q} / \mathrm{ha}$, when foliar spraying was done with Pseudomonas fluorescens. The foliar spray with Trichoderma viride and Pseudomonas fluoroscens with priming of seeds were also proved effective by reducing the disease by $78.0 \%$ and $73.0 \%$ as well as increasing the yield by $42.4 \%$ and $43.7 \%$ respectively. Considering the effects of cultural practices such as the removal of infected lower leaves and staking of plants could reduce the disease by $50.2 \%$ and thereby increasing the fruit yield over control about $26.5 \%$ which recorded 1: 9.7 cost benefit ratio and found to be the best in all respect.

\section{Introduction}

Tomato (Lycopersicon esculentum Mill.) belongs to family solanaceae and is the second most important vegetable crop next to potato. Tomato is highly sensitive to environmental stresses and remarkable losses in yield are caused by several diseases. About 200 diseases have been reported on tomato.
Among these early blight (Alternaria solani), late blight (Phytophthora infestans), bacterial wilt and brown rot (Ralstonia solanacearum) and leaf curl complex are most common and serious diseases of tomato worldwide including India? However the early blight caused by Alternaria solani is a major 
production constraint in tomato wherever the crop is grown. Early blight is wide spread throughout the tropics and temperate zones (Waals et al., 2004). In India the disease occurs in all parts of the country which causes loss in fruit yield. The loss in yield due to early blight disease in tomato was 0.75 to 0.77 t/ha for every $1 \%$ increase in disease severity (Saha and Das, 2012). As high as 86 per cent yield loss has been reported (50$86 \%$ ) in tomato (Mathur and Sekhawat, 1986). Every one percent increase in intensity can reduce yield by 1.36 per cent and complete crop failure can occur when the disease severity is high (Ngoc et al., 2013). Among fungal diseases blight caused by Alternaria species was the most predominant with the crop loss in the field ranging from 70-100 per cent as reported from a survey and loss assessment in West Bengal India (Kanjilal et al., 2000). Keeping in view the fungicidal hazards to nature and development of resistance of pathogenic fungi towards chemicals; the environmentally safe methods of crop protection are to be experimented. Application of Trichoderma viridae both to seed and soil may be used as an effective treatment to achieve disease reduction and develop ecofriendly strategy in tomato (Nirupama Devi et al., 2013). Even detachment of diseased foliage may slower down the rate of disease spread and can be integrated with other cultural and biological management approaches. Several bioagents were also found antagonistic against fungal pathogens. Hence the present investigation based on an integration of biological and cultural methods of blight and fruit rot management in tomato.

\section{Materials and Methods}

In order to study the synergistic effect of cultural practice, seed priming with bioagent along with foliar spray with antagonistic fungi and bacteria on management of Alternaria blight of tomato, field trials were conducted for three consecutive seasons of Rabi 201011, 2011-12 and 2012-13 in the farmers' field at Tirtol of Jagatsinghpur district of Odisha with the test variety Utkal Kumari (BT-10).

The trail was laid out in Randomized Block Design with three replications. The various treatments included under study were as follows: $\mathrm{T}_{1}=$ Removal of infected lower leaves, staking of plants, $\mathrm{T}_{2}=$ Seed priming with Sanjeevani $(6 \mathrm{gm} / \mathrm{kg}), \mathrm{T}_{3}=\mathrm{T}_{1}+\mathrm{T}_{2}, \mathrm{~T}_{4}=$ $\mathrm{T}_{1}+$ Spraying with Trichoderma viride, $\mathrm{T}_{5}=$ $\mathrm{T}_{1}+$ Spraying with Pseudomonas fluorescens, $\mathrm{T}_{6}=\mathrm{T}_{2}+$ Spraying with $\mathrm{T}$. viride, $\mathrm{T}_{7}=\mathrm{T}_{2}+$ Spraying with $P$. fluorescens, $\mathrm{T}_{8}=\mathrm{T}_{3}+$ Spraying with $T$. viride, $\mathrm{T}_{9}=\mathrm{T}_{3}+$ Spraying with $P$. fluorescens, $\mathrm{T}_{10}=$ Control (untreated)

The seed treatment was done 24 hours before sowing. Sanjeevani is Trichoderma viride based biofungicide available commercially (International Panaacea Ltd., New Delhi) in solid formulation. For cultural management, staking of plants as well as removal of infected lower leaves was practiced after appearance of disease symptoms in the field. The crop was planted with a row to row spacing of $60 \mathrm{~cm}$ and plant to plant spacing of $40 \mathrm{~cm}$, being adopted in a plot size of 8.1sq.mt. (3.0m x $2.7 \mathrm{~m}$ ). All the agronomic practices as generally recommended was followed with the fertilizer dose of $\mathrm{N}_{2}: \mathrm{P}_{2} \mathrm{O}_{5}$ : $\mathrm{K}_{2} \mathrm{O}:$ : $125: 60$ : $100 \mathrm{~kg} / \mathrm{ha}$. First foliar spraying of bioagents was applied at the initiation of disease followed by 2 nd spray at 10 days interval. The percent disease incidence (PDI) and percent disease control (PDC) were calculated (Wheeler, 1969). The observations were taken to find out the marketable as well as rotted fruit yield. Economics of ecofriendly management was worked out on the basis of prevailing market price of tomato fruits @ Rs. 800/- per quintal, labourwas@ Rs. 200/-per day per person and cost of the bioagents. 


\section{Results and Discussion}

The data presented in Table 1, 2 and 3 revealed that the removal of infected lower leaves, staking of plants, seed priming with Sanjeevani along with foliar spray of antagonistic fungus Trichoderma viride $\left(\mathrm{T}_{8}\right)$ and Pseudomonas fluroscens $\left(\mathrm{T}_{9}\right)$ recorded the lowest mean PDI of 3.4 and 5.8 respectively reducing the incidence of disease by 93.4 and 88.8 per cent respectively over control. The average incidence of early blight was recorded the highest PDI of 51.80 in untreated control and it is in close conformity with the range of blight incidence(23.44 to 70.94 per cent) as reported by Munde et al., (2013).

The treatment $\mathrm{T} 8$ recorded significantly lower mean PDI and also maximum mean fruit yield of $328.4 \mathrm{q} / \mathrm{ha}$ as compared to $218.1 \mathrm{q} / \mathrm{ha}$ in control plot.

$\mathrm{T}_{9}$ was found at par with $\mathrm{T}_{8}$ and significantly higher than any other treatment which recorded $324.9 \mathrm{q} /$ ha of marketable fruits. The increase in marketable fruit over control was $50.6 \%$ in $\mathrm{T} 8$ followed by $49.0 \%$ in $\mathrm{T}_{9}$.

Table.1 Effect of ecofriendly management on incidence of Alternaria blight and fruit rot in tomato

\begin{tabular}{|l|c|c|c|c|c|}
\hline \multicolumn{1}{|c|}{ Treatments } & \multicolumn{3}{|c|}{$\begin{array}{c}\text { Mean Percent Disease } \\
\text { Incidence (PDI) }\end{array}$} & Mean & $\begin{array}{c}\text { \% disease } \\
\text { reduction }\end{array}$ \\
\hline $\begin{array}{l}\mathrm{T}_{1}: \text { Removal of infected lower leaves, } \\
\text { staking of plants }\end{array}$ & 26.4 & 25.8 & 25.2 & 25.8 & 50.2 \\
\hline $\mathrm{T}_{2}:$ Seed priming with Sanjeevani & $(30.89$ & $(30.49)$ & $(30.10)$ & $(30.49)$ & \\
& 25.6 & 22.3 & 23.4 & 23.8 & 54.1 \\
\hline $\mathrm{T}_{3}: \mathrm{T}_{1}+\mathrm{T}_{2}$ & $(30.37)$ & $(28.15)$ & $(28.84)$ & $(29.12)$ & \\
& $(25.1$ & 19.4 & 20.0 & 19.2 & 62.9 \\
\hline $\mathrm{T}_{4}: \mathrm{T}_{1}+$ Spraying Trichoderma viride & 15.1 & $(26.11)$ & $(26.56)$ & $(25.93)$ & \\
& $(22.81)$ & $(23.75)$ & 15.8 & 15.7 & 69.7 \\
\hline $\mathrm{T}_{5}: \mathrm{T}_{1}+$ Spraying Pseudomonas fluoroscens & 16.8 & 17.1 & 16.0 & $(23.28)$ & \\
\hline $\mathrm{T}_{6}: \mathrm{T}_{2}+$ Spraying T. viride & $(24.06)$ & $(24.38)$ & $(23.56)$ & $(24.00)$ & 68.0 \\
& 10.8 & 12.1 & 11.4 & 11.4 & 78.0 \\
\hline $\mathrm{T}_{7}: \mathrm{T}_{2}+$ Spraying P. fluoroscens & $(19.07)$ & $(20.33)$ & $(19.69)$ & $(19.70)$ & \\
\hline $\mathrm{T}_{8}: \mathrm{T}_{3}+$ Spraying T. viride & 14.1 & 13.2 & 14.8 & 14.0 & 73.0 \\
& $(21.93)$ & $(21.20)$ & $(22.51)$ & $(21.88)$ & \\
\hline $\mathrm{T}_{9}: \mathrm{T}_{3}+$ Spraying P. fluoroscens & 2.5 & 3.6 & 4.1 & 3.4 & 93.4 \\
& $(9.05)$ & $(10.81)$ & $(11.61)$ & $(10.49)$ & \\
\hline $\mathrm{T}_{10}:$ Control & 5.8 & 6.4 & 5.1 & 5.8 & 88.8 \\
& $(12.46)$ & $(14.43)$ & $(12.99)$ & $(13.29)$ & \\
\hline $\mathrm{SE}(\mathrm{m}) \pm$ & 48.2 & 54.5 & 52.8 & 51.8 & - \\
\hline $\mathrm{CD}(0.05)$ & $(43.96)$ & $(47.67)$ & $(46.61)$ & $(46.08)$ & \\
\hline $\mathrm{CV}(\%)$ & 1.24 & 1.01 & 0.87 & 0.54 & \\
\hline
\end{tabular}


Table.2 Effect of the integrated ecofriendly approach of blight management on Fruit yield of tomato

\begin{tabular}{|c|c|c|c|c|c|c|c|c|c|}
\hline \multirow[t]{2}{*}{ Treatments } & \multicolumn{3}{|c|}{$\begin{array}{l}\text { Marketable fruit yield } \\
\text { (Q/ha) }\end{array}$} & \multirow[t]{2}{*}{ Mean } & \multirow{2}{*}{$\begin{array}{l}\% \text { yield } \\
\text { increase } \\
\text { over } \\
\text { control }\end{array}$} & \multicolumn{3}{|c|}{ Rotted fruit yield (Q/ha) } & \multirow[t]{2}{*}{ Mean } \\
\hline & $\begin{array}{c}2010- \\
11\end{array}$ & $\begin{array}{c}2011- \\
12\end{array}$ & $\begin{array}{c}2012- \\
13\end{array}$ & & & $\begin{array}{c}2010- \\
11\end{array}$ & $\begin{array}{c}2011- \\
12\end{array}$ & $\begin{array}{c}2012- \\
13\end{array}$ & \\
\hline $\begin{array}{l}\mathrm{T}_{1} \text { : Removal of } \\
\text { infected lower leaves, } \\
\text { staking of plants }\end{array}$ & 275.6 & 278.3 & 274.1 & 276.0 & 26.5 & 30.1 & 31.6 & 28.3 & 30.0 \\
\hline $\begin{array}{l}\mathrm{T}_{2}: \text { Seed priming with } \\
\text { Sanjeevani }\end{array}$ & 278.6 & 280.3 & 282.4 & 280.4 & 28.6 & 32.4 & 31.3 & 33.6 & 32.4 \\
\hline $\mathrm{T}_{3}: \mathrm{T}_{1}+\mathrm{T}_{2}$ & 295.3 & 297.4 & 299.6 & 297.4 & 36.4 & 31.6 & 27.4 & 28.1 & 29.0 \\
\hline $\begin{array}{l}\mathrm{T}_{4}: \mathrm{T}_{1}+\text { Spraying } \\
\text { Trichodermaviride }\end{array}$ & 308.5 & 310.6 & 307.3 & 308.8 & 41.6 & 24.6 & 26.4 & 27.3 & 26.1 \\
\hline $\begin{array}{l}\mathrm{T}_{5}: \mathrm{T}_{1}+\text { Spraying } \\
\text { Pseudomonas } \\
\text { fluoroscens }\end{array}$ & 303.6 & 304.8 & 302.1 & 303.5 & 39.2 & 27.3 & 29.2 & 29.9 & 28.8 \\
\hline $\begin{array}{l}\mathrm{T}_{6}: \mathrm{T}_{2}+\text { Spraying } T . \\
\text { viride }\end{array}$ & 310.8 & 308.4 & 312.6 & 310.6 & 42.4 & 20.3 & 22.4 & 25.6 & 22.8 \\
\hline $\begin{array}{l}\mathrm{T}_{7}: \mathrm{T}_{2}+\text { Spraying } P . \\
\text { fluoroscens }\end{array}$ & 315.4 & 311.2 & 313.6 & 313.4 & 43.7 & 22.2 & 24.8 & 22.8 & 23.3 \\
\hline $\begin{array}{l}\mathrm{T}_{8}: \mathrm{T}_{3}+\text { Spraying } T \\
\text { viride }\end{array}$ & 330.6 & 325.8 & 328.9 & 328.4 & 50.6 & 15.2 & 11.8 & 13.0 & 13.3 \\
\hline $\begin{array}{l}\mathrm{T}_{9}: \mathrm{T}_{3}+\text { Spraying } P . \\
\text { fluoroscens }\end{array}$ & 325.3 & 323.4 & 326.1 & 324.9 & 49.0 & 17.1 & 18.2 & 18.8 & 18.0 \\
\hline $\mathrm{T}_{10}:$ Control & 218.4 & 220.4 & 215.6 & 218.1 & - & 36.4 & 38.3 & 38.0 & 37.6 \\
\hline $\mathrm{SE}(\mathrm{m}) \pm$ & 4.11 & 2.59 & 3.16 & 1.21 & & 2.33 & 2.75 & 2.21 & 0.96 \\
\hline $\mathrm{CD}(0.05)$ & 12.20 & 7.70 & 9.38 & 3.61 & & 6.93 & 8.17 & 6.57 & 2.85 \\
\hline $\mathrm{CV}(\%)$ & 2.41 & 1.51 & 1.85 & 0.71 & & 15.72 & 18.22 & 14.43 & 6.36 \\
\hline
\end{tabular}

Table.3 Economics of the ecofriendly approach of Alternaria blight management in tomato

\begin{tabular}{|l|c|c|c|c|c|}
\hline \multicolumn{1}{|c|}{ Treatments } & $\begin{array}{c}\text { Excess produce } \\
\text { over control } \\
\text { (q/ha) }\end{array}$ & $\begin{array}{c}\text { Gross expenditure } \\
\text { over control } \\
\text { (Rs/ha) }\end{array}$ & $\begin{array}{c}\text { Gross return } \\
\text { over control } \\
\text { (Rs/ha) }\end{array}$ & $\begin{array}{c}\text { Net return } \\
\text { over control } \\
\text { (Rs/ha) }\end{array}$ & $\begin{array}{c}\text { B:C } \\
\text { ratio }\end{array}$ \\
\hline $\begin{array}{l}\mathrm{T}_{1}: \text { Removal of infected lower } \\
\text { leaves, staking of plants }\end{array}$ & 58.0 & 4450 & 46,400 & 41,950 & 9.4 \\
\hline $\begin{array}{l}\mathrm{T}_{2}: \text { Seed priming with } \\
\text { Sanjeevani }\end{array}$ & 62.4 & 4220 & 49,920 & 45,700 & 10.8 \\
\hline $\mathrm{T}_{3}: \mathrm{T}_{1}+\mathrm{T}_{2}$ & 79.4 & 5815 & 63,520 & 57,705 & 9.9 \\
\hline $\begin{array}{l}\mathrm{T}_{4}: \mathrm{T}_{1}+\text { Spraying } \\
\text { Trichodermaviride }\end{array}$ & 90.8 & 6930 & 72,640 & 65,710 & 9.5 \\
\hline $\begin{array}{l}\mathrm{T}_{5}: \mathrm{T}_{1}+\text { Spraying Pseudomonas } \\
\text { fluoroscens }\end{array}$ & 85.5 & 7630 & 68,400 & 60,770 & 8.0 \\
\hline $\mathrm{T}_{6}: \mathrm{T}_{2}+$ Spraying T. viride & 92.6 & 6240 & 74,080 & 67,840 & 10.9 \\
\hline $\mathrm{T}_{7}: \mathrm{T}_{2}+$ Spraying $P$. fluoroscens & 95.4 & 6940 & 76,320 & 69,380 & 10.0 \\
\hline $\mathrm{T}_{8}: \mathrm{T}_{3}+$ Spraying T. viride & 110.4 & 8270 & 88,320 & 80,050 & 9.7 \\
\hline $\begin{array}{l}\mathrm{T}_{9}: \mathrm{T}_{3}+\text { Spraying } P . \\
\text { fluoroscens }\end{array}$ & 106.9 & 8970 & 85,520 & 76,550 & 8.5 \\
\hline $\mathrm{T}_{10}:$ Control & - & - & - & & - \\
\hline
\end{tabular}


Seed treatment with Sanjeevani along with foliar spray of $T$. viride $\left(\mathrm{T}_{6}\right)$ and seed treatment with Sanjeevani along with foliar spray of $P$. fluroscens $\left(\mathrm{T}_{7}\right)$ were also proved effective by reducing the disease by 78.0 per centand 73.0 per cent respectively as well as increasing the yield by 42.4 per cent and 43.7per cent respectively. However the yield obtained from $\mathrm{T}_{6}(310.6 \mathrm{q} / \mathrm{ha})$ and $\mathrm{T}_{7}$ $(313.4 \mathrm{q} / \mathrm{ha})$ are statistically at par with each other. The minimum rotted fruits (13.3q/ha) were harvested from $\mathrm{T} 8$ as compared to $37.6 \mathrm{q} / \mathrm{ha}$ from control plot.

Considering the effects of cultural practices $\mathrm{T}_{1}$ i.e. removal of infected lower leaves and staking of plants could be able to reduce the disease by $50.2 \%$ and there is increase in fruit yield over control about $26.5 \%$ which recorded 1:9.7 $\mathrm{C}: \mathrm{B}$ ratio and found to be the best in all respects. Effectiveness of Pseudomonas fluoroscens as a potent biocontrol agent has been demonstrated earlier by Babu et al., (2000), Ngoc et al., (2013) and Mahapatra and Swain (2013) which is in line with the present study. Foliar spraying with Trichoderma viride and $T$. harzianum were also successfully demonstrated to manage Alternaria porri, causing purple blotch of onion by Mishra and Gupta (2008).

Mahapatra and Swain (2013) reported 82.82\% disease control by spraying with $T$. viride and $78.24 \%$ disease control by spraying with $P$. fluoroscens against pod rot of ground nut. The cultural practices like staking of the plants to minimize the incidence has been reported earlier by Bharadwaj et al., (1995) and detachment of lower leaves by Rathee et al., (2006) and Hooda et al., (2008), which confirmed the present findings. Therefore, an economic, effective, ecofriendly and integrated approach has been taken to manage the early blight pathogen under Odisha condition.

\section{References}

Babu, S., Seetharaman, K., Nanda, K. R., and Johnson, I. 2000. Biocontrol efficacy of Pseudomonas fluorescens against Alternaria solania nd tomato leaf blight disease. Annals Plant Prot. Sci.8:252254.

Bharadwaja, C.L., Thakur, D.R., and Jamwal, R.S. 1995. Effect of Fungicide spray and staking, on diseases and disorders of tomato. Indian J. Agric.Sci.65: 148151.

Hooda, K.S., Bhatt, J.C., Joshi, D., Sushil, S.N., and Gupta, H.S. 2008. Bio control agents vis-à-vis fungicides in managing various diseases of tomato (Lycopersicon esculentum Mill.) in hills of Uttarakhand. Indian Phytopath.61 (3):331-336.

Kanjilal, S., Samaddar, K.R. and Samajpati, N. 2000. Field disease and potential of tomato cultivation in West Bengal. J.Mycopathol. Res.38: 121-123.

Mahapatra, S.S., and Swain, N.C. 2013. Biological management of pod rot disease of groundnut. J. Plant Prot. Environ. 10: 48-52.

Mathur, K., and Sekhawat, K..S. 1986. Chemical control of early blight in Kharif sown tomato. Indian J.Mycol. Pl. Pathol. 16:235-238.

Mishra, R.K., and Gupta, R.P. 2008 Screening of Antagonists against Alternaria porricausin purple blotch of onion $J$. Mycol. Pl. Pathol. 38: 645-656.

Munde, V.G., Diwakar, M.P., Thombre, B.B., and Dey, U. 2013.Screening of tomato cultivars against early blight under field conditions. Indian Phytopath.66 (4):408-410.

Ngoc, N.K., Narendrapa, T., and Chaudhary, M. 2013. Management of Tomato early blight disease Alternaria solani (Elis and Martin) Jones and Grout, through Biological and Chemical Methods. 
Mysore. J. Agric. Sci.47: 241-245.

Nirupama Devi, T., Linthoingambi, W., and

Singh, M.S. 2013. Evaluation of Trichoderma species against Fusarium oxysporum f.sp. lycopersici for biological control of tomato wilt. Indian Phytopath.66 (1): 81-87.

Rathee, V.K., Goutam, G., Sharma, K.C., and Verma, S. 2006. Chemical and biological control of foliar and fruit rot disease of tomato. PI. Dis. Res. 21: 5354.
Saha, P., and Das, S. 2012. Assessment of Yield Loss Due to Early Blight (Alternaria solani) in Tomato. Indian $J$. Plant Prot.40: 195-198.

Waals, J.E., Vender, K.L., and Slipper, B. 2004. Genetic diversity among Alternaria solani isolates from potatoes in South Africa. Plant Dis. 88: 959-964.

Wheeler, B. E. J., 1969. An introduction to plant diseases. John Wiley and Sons Ltd., London.

\section{How to cite this article:}

Dhal, A., S.K. Beura, S.K. Dash, L. Tripathy, S.K. Swain and Sethi, D. 2017. Eco-Friendly and Integrated Approaches for Management of Early Blight Disease in Tomato. Int.J.Curr.Microbiol.App.Sci. 6(10): 3052-3057. doi: https://doi.org/10.20546/ijcmas.2017.610.359 